\title{
EFFECT OF INDUSTRY EFFLUENT ON HISTO-PHARMACOGNOSY OF BOERHAAVIA DIFFUSA LINN. USED AS BLOOD PURIFIER
}

\author{
Kavita Tyagi and Saurabh Sharma
}

National Medicinal Plants Board, Ministry of AYUSH

Govt. of India, Red Cross Society, New Delhi, India

\section{Research Article}

Received: 12.06.2021

Accepted: 18.06.2021

Published: 29.06.2021

\begin{abstract}
Aims of the Study:

To carried out the effect of Atlas Cycles Industry effluent on pharmacognosy of Boerhaavia diffusa Linn. used as Blood Purifier

\section{Method:}

The effluent of Atlas Cycles Industry was analyzed by Trivedi \& Goel, 1986 method. Metacalf and Chalk, 1950 was consulted for anatomical studies of selected plant; for chemical analysis Johanson, 1940, Cromwell, 1955 \& Trease and Evans, 1983 were followed. TLC was investigated by WHO, 1998.

\section{Results:}

The physico-chemical parameters of Atlas cycle industry effluent were found greater values as compared to standard values. The morphological \& anatomical parameters were showed decreasing trend in those plants which were collected near the vicinity of Atlas cycle industry. The colour reaction tests resulted only degrees of changes. The number of spots in observation of TLC, stomatal index, palisade ratio, water extractive and alcohol extractive values were reduced in those plants which were collected near the vicinity of Atlas cycle industry where as vein Islet \& vein termination number, ash values were comparatively higher in same samples.

\section{Conclusion:}

The conclusion of this study is that the plants should not be collected form polluted areas(near the vicinity of any industry) for the preparation of medicines, since majority of parameters reflect decreasing data in those plants which were taken from polluted area.
\end{abstract}

Keywords: Pharmacognosy, Boerhaavia diffusa, Effluent analysis.

\section{INTRODUCTION}

After making a survey of Ghaziabad, it is found that most of the industries are situated near the agricultural land and populated areas. The industrial wastes are being discharged in the earthen and semi earthen areas (fields). In these areas many medicinally important plants are growing. Boerhaavia diffusa Linn. an important medicinal plant is selected in this study which is found in the vicinity of Atlas Cycles Industry, Ghaziabad. The heavy metals and other pollutants enter into the roots of medicinally important plants through industrial effluent and agricultural wastes. Bio-monitors are of the view that the polluted water which is an intricate system of living and nonliving substances like acids, alkalis, chlorides, heavy

*Corresponding author: kavitatyagii@gmail.com 
metals, dissolved solids, nitrates, sulfates, aquatic life bacteria, fungal forms etc. they are harmful to environment and plant species thus caused a numbers of changes in the morphology, anatomy, chemical constituents, behaviour and reproductive cycle, the flora and fauna of the region. The pollution in the region has affected the growth of various plant species having substantial medicinal value.

Pharmaco-botanical analysis plays a vital role in identification of plants and determination of their purity and quality of raw medicinal material plant. Therefore, an attempt has been made for a comparative study under the impact of industrial pollution on $B$. diffusa. It is a very important medicinal plants having anti-tumor property and commonly used as a blood purifier.

\section{MATERIALS AND METHODS}

The samples of Boerhaavia diffusa Linn. were collected from the area near to Atlas Cycle Industry,
Sahibabad, Ghaziabad, UP, India to investigate the effect of industrial pollution. The effluent was analyzed by using the standard methods of Trivedi \& Goel (1986). Fresh and matured samples of both the plants are collected from polluted (Atlas Cycle Industry) and non-polluted areas (ALTT Centre, Ghaziabad) to their macro morphological characters. For anatomical studies Metacalf (1980) were consulted. For chemical analysis Johanson, 1940, Cromwell, 1955 \& Trease and Evans, 1983 were followed. TLC was investigated by WHO, 1998.

\section{RESULTS}

\section{Analysis of Effluent}

The effluent contains data regarding Colour, Odour, BOD, COD, DO, pH, temperature, TS, TSS, TDS, oil and grease, heavy metals etc. The result is given in table -1 .

Table 1: Physico-chemical Characteristics of industrial effluent of Atlas Cycle Industry.

\begin{tabular}{|c|c|c|c|c|}
\hline S.No. & Parameters & $\begin{array}{l}\text { Characteristic of } \\
\text { Effluents }\end{array}$ & $\begin{array}{l}\text { Maximum } \\
\text { Recommended } \\
\text { Concentration }\end{array}$ & $\begin{array}{l}\text { Authority/ } \\
\text { Reference }\end{array}$ \\
\hline 1. & Colour & Yellowish & Should be absent & I.S.I. : 2490 \\
\hline 2. & Odour & -- & Odourless & I.S.I. : 2490 \\
\hline 3. & $\mathrm{pH}$ & $4-6$ & $5.5-9.0$ & I.S.I. : 2296 \\
\hline 4. & Suspended Solids & $200 \mathrm{mg} / \mathrm{l}$ & $\begin{array}{ll}---- \\
--1\end{array}$ & $\begin{array}{ll}---- \\
--1\end{array}$ \\
\hline 5. & Total Dissolved Solids (mg/l) & $810 \mathrm{mg} / \mathrm{l}$ & 2100.0 & I.S.I. : 3307 \\
\hline 6. & Total Suspended Solids (mg/l) & $1010 \mathrm{mg} / \mathrm{l}$ & 600.0 & I.S.I. : 3306 \\
\hline 7. & Dissolved Solids & $720 \mathrm{mg} / \mathrm{l}$ & ------- & ------------ \\
\hline 8. & Total Solids (mg/l & $840 \mathrm{mg} / \mathrm{l}$ & 2700.0 & - - \\
\hline 9. & BOD (mg/l) & $16.0 \mathrm{mg} / \mathrm{l}$ & 30.0 & I.S.I. : 2490 \\
\hline 10. & COD (mg/l) & $200 \mathrm{mg} / \mathrm{l}$ & 250.0 & I.S.I. : 2490,1982 \\
\hline 11. & Oil and Grease (mg/l) & Nil & 10.0 & I.S.I. : 2490 \\
\hline 12 & Chloride (mg/l) & Nil & 600 & I.S.I. : 2490 \\
\hline 14 & Chromium (Cr) & $5 \mathrm{mg} / \mathrm{l}$ & ------- & ---------- \\
\hline 15. & Nickel (Ni) & $12 \mathrm{mg} / \mathrm{l}$ & ------ & --------- \\
\hline 16. & Zinc (Zn) & $15 \mathrm{mg} / \mathrm{l}$ & ------- & ---------- \\
\hline 17. & Cadmium (Cd) & $4 \mathrm{mg} / \mathrm{l}$ & ------ & ---------- \\
\hline 18. & Copper (Cu) & $4 \mathrm{mg} / \mathrm{l}$ & ------ & --------- \\
\hline 19. & Temperature & $500 \mathrm{C}$ & ------- & ---------- \\
\hline
\end{tabular}




\section{Pharmacognostic Studies:}

Organoleptic Studies: Macroscopical: Stem is prostrate, ascending, reaching $0.6-0.9 \mathrm{~m}$ long, often purplish, swollen at the nodes, divaricately branched, slender, cylindrical, minutely pubescent or nearly glabrous. Leaves are arranged in unequal pairs at each node, 1.0-5.0 cm long and 2.5-3.0 cm broad, dark green in colour, ovate, oblong, rounded at apex, glabrous, usually containing white minute scales beneath, base rounded, margin entire, often pink; petiole nearly as long as the blade i.e. 2.0-2.6 cm long and solid in non polluted (fig. a) sites whereas in polluted sites leaves are light green in colour with some white brown patches; petiole solid $1.5-2.0 \mathrm{~cm}$ long ( fig. b).

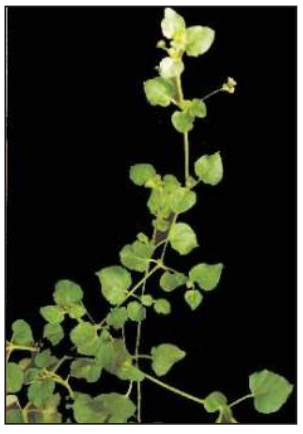

a.

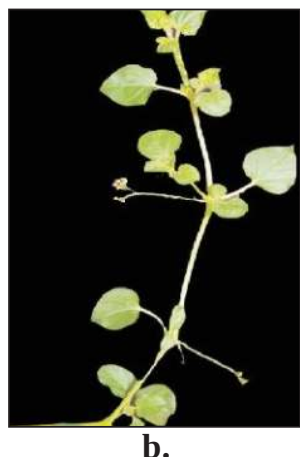

b.
Fig. 1: Morphological differences of Boerhaavia diffusa Linn. growing in non polluted (a) and polluted (b) areas. Flowers red, pink or white, in small umbels arranged in axillary and terminal panicles; fruits ovate oblong, pubescent, fiveribbed, viscid glandular anthocarps in both the cases. The main differences are in Plate-1(a\&b).

Microscopical: Anatomy / Histology: Stem: Single layer circular epidermis covered by thin cuticle with glandular and nonglandular trichomes; hypodermis 34 layered collenchymatous followed by 3-5 layers of chlorenchymatous cortex; endodermis well distinct, single layered made up of barrel shaped cells; pericycle represented by few patches of fibers. Vascular bundles arranged in three rings. There are 1520 vascular bundles in outer ring, 6-14 in middle ring and two large vascular bundles present in inner ring. Pith is large and parenchymatous cell containing micro, rosette and prismatic crystals of calcium oxalate in case of non polluted plants. In case of polluted plants thick cuticle, 5-6 layers of parenchyma, cambium discontinuous and absence of chlorenchyma were observed. The main differences are in Plate 2 (a \& b).

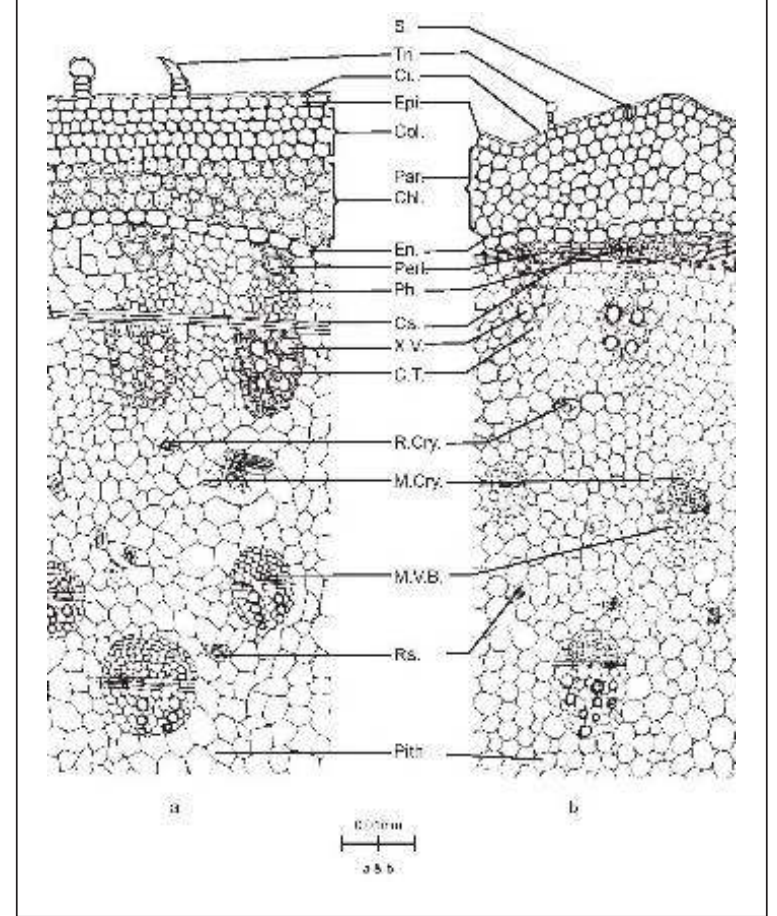

Plate-2: Anatomical differences in stem of Boerhaavia diffusa Linn.growing in non polluted (a) and polluted (b)areas.

Leaf :- Single layer of epidermis with glandular and non-glandular trichomes; stomata anisocytic and anomocytic found on both the surfaces. Mesophyll differentiated into two regions; 2 layers of palisade and 4-5 layers of spongy parenchyma. Midrib having 4-5 vascular bundles, arranged in arc, raphide (acicular crystal) and microcrystal present in parenchyma of ground tissue in leaf collected from non polluted areas (a\&b). The leaf collected from polluted sites shows 2 layered epidermis, 2 layers of collenchyma below the upper epidermis, mesophyll with single layer of palisade and 3-4 layers of spongy parenchyma; one vascular bundle in midrib (c\&d). Rosette, micro and idioblasts containing raphides are present in parenchymatous cells. The stomatal index is 16.12 20.00 on upper epidermis and 13.93 - 17.64 on lower surfaces in non-polluted leaf. But in case of polluted leaf the stomatal index is $12.70-16.27$ on upper epidermis and 9.09- 14.81 in lower epidermis. The Palisade ratio is $10.75-11.50$ in non polluted leaf and $6.25-6.95$ in polluted leaf. The vein islet number are $12-16$ in non-polluted and $8-10$ in polluted samples. The vein termination number values are 14 - 24 in non polluted and 18- 36 in polluted samples (table 2). The main differences are in Plate- 3. 


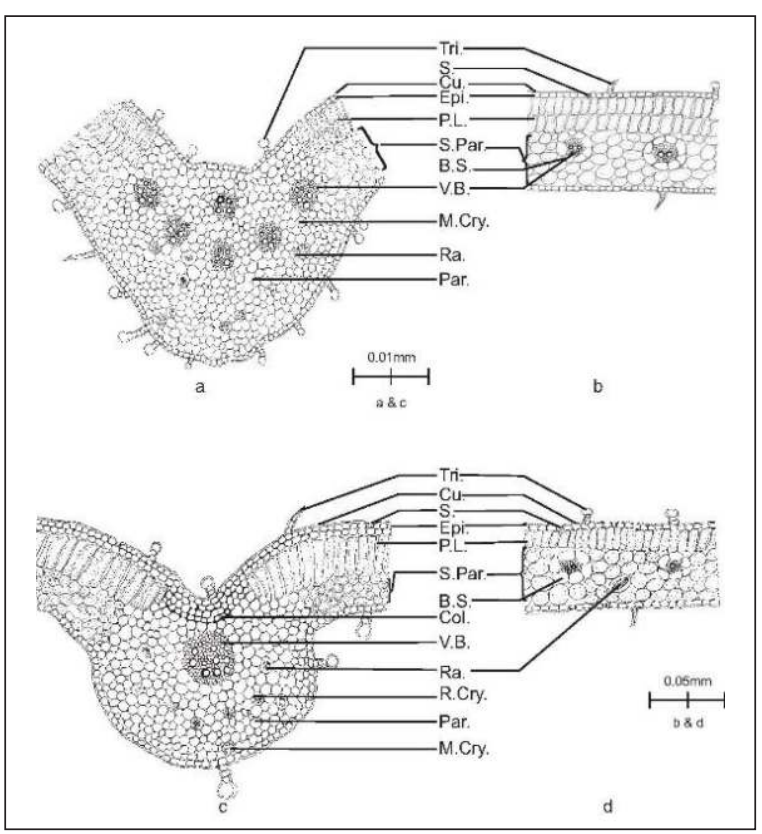

Plate 3: Anatomical differences in the leaves of Boerhaavia diffusa Linn. growing in non polluted (a through midrib) \& (b through lamina) and polluted areas (c through midrib) \&( through lamina d).
Powder Analysis:- The colour of powder is green in non polluted plant samples and brown green in

Table 2: Powder analysis of Boerhaavia diffusa Linn. growing in non-polluted and polluted areas.

\begin{tabular}{|c|c|c|c|}
\hline \multicolumn{4}{|c|}{ Powder Analysis } \\
\hline S.No. & Characters & Non-polluted & Polluted \\
\hline 1. & Xylem Vessel (mm) & $\begin{array}{r}\mathrm{L}=0.62+0.08 ; \mathrm{CV}=12.90 \\
\mathrm{~W}=0.07+0.009 ; \mathrm{CV}=12.90\end{array}$ & $\begin{array}{r}\mathrm{L}=0.28+0.03 * ; \mathrm{CV}=14.06 \\
\mathrm{~W}=0.06+0.01 * ; \mathrm{CV}=28.78\end{array}$ \\
\hline 2. & Diameter of Xylem Pore (mm) & $\mathrm{D}=0.13+0.02 ; \mathrm{CV}=10.89$ & $\mathrm{D}=0.08+0.009 * ; \mathrm{CV}=10.69$ \\
\hline 3. & Xylem Tracheid (mm) & $\begin{array}{r}L=1.37+0.05 ; C V=3.65 \\
W=0.15+0.05 ; C V=38.16\end{array}$ & $\begin{aligned} \mathrm{L} & =0.14+0.007 ; \mathrm{CV}=5.00 \\
\mathrm{~W} & =0.07+0.01 * ; \mathrm{CV}=23.07\end{aligned}$ \\
\hline 4. & Xylem Fibre (mm) & $\begin{aligned} \mathrm{L} & =1.07+0.12 ; \mathrm{CV}=11.81 \\
\mathrm{~W} & =0.06+0.09 ; \mathrm{CV}=14.39\end{aligned}$ & $\begin{array}{l}\mathrm{L}=0.80+0.15^{* *} ; \mathrm{CV}=19.26 \\
\mathrm{~W}=0.06+0.006 ; \mathrm{CV}=10.20\end{array}$ \\
\hline 5. & Palisade Cell (mm) & $\begin{array}{l}\mathrm{L}=0.087+0.009 ; C V=10.34 \\
W=0.04+0.003 ; C V=7.14\end{array}$ & $\begin{array}{r}\mathrm{L}=0.15+0.012 * ; \mathrm{CV}=7.89 \\
\mathrm{~W}=0.05+0.006 * ; \mathrm{CV}=11.53\end{array}$ \\
\hline 6. & Palisade Ratio & $\begin{array}{r}\mathrm{R}=10.75-11.50 \\
\mathrm{SD}=11.06+0.32 ; \mathrm{CV}=2.89\end{array}$ & $\begin{array}{r}\mathrm{R}=6.25-6.95 \\
\mathrm{SD}=6.675+0.26^{*} ; \mathrm{CV}=3.86\end{array}$ \\
\hline 7. & Spongy Parenchyma (mm) & $\begin{array}{r}\mathrm{L}=0.06+0.003 ; \mathrm{CV}=4.83 \\
\mathrm{~W}=0.042+0.009 ; \mathrm{CV}=21.42\end{array}$ & $\begin{array}{ll}L=0.140+0.007 ; & C V=5.00 \\
W=0.07+0.004 * ; & C V=5.63\end{array}$ \\
\hline 8. & Guard Cell (mm) & $\begin{array}{r}\mathrm{L}=0.15+0.003 ; \mathrm{CV}=2.04 \\
\mathrm{~W}=0.04+0.003 ; \mathrm{CV}=.14\end{array}$ & $\begin{array}{l}\mathrm{L}=0.095+0.002 * ; C V=2.10 \\
\mathrm{~W}=0.03+0.004 * ; C V=12.50\end{array}$ \\
\hline 9. & Stomatal Pore (mm) & $\begin{array}{r}L=0.127+0.006 ; C V=4.72 \\
W=0.042+0.006 ; C V=10.90\end{array}$ & $\begin{array}{r}\mathrm{L}=0.076+0.008 * ; \quad \mathrm{CV}=10.56 \\
\mathrm{~W}=0.03+0.003 * ; \quad \mathrm{CV}=9.09\end{array}$ \\
\hline 10. & Stomatal Index (Upper Surface) & $\begin{array}{r}\mathrm{R}=16.13-20.00 \\
\mathrm{SD}=17.68+1.33 ; \mathrm{CV}=7.52\end{array}$ & $\begin{array}{r}\mathrm{R}=12.724-16.279 \\
\mathrm{SD}=14.11+1.36 ; \mathrm{CV}=15.52\end{array}$ \\
\hline
\end{tabular}




\begin{tabular}{|l|l|r|r|}
\hline 11. & Stomatal Index (Lower Surface) & $\begin{array}{r}\mathrm{R}=13.93-17.65 \\
\mathrm{SD}=15.41+1.56 ; \mathrm{CV}=10.17\end{array}$ & $\begin{array}{r}\mathrm{R}=9.09-14.81 \\
\mathrm{SD}=13.84+1.052 ; \mathrm{CV}=7.60\end{array}$ \\
\hline 12. & Raphide $(\mathrm{mm})$ & $\begin{array}{r}\mathrm{L}=0.090+0.03 ; \mathrm{CV}=31.63 \\
\mathrm{~W}=0.075+0.02 ; \mathrm{CV}=31.33\end{array}$ & $\begin{array}{r}\mathrm{L}=0.10+0.01^{*} ; \mathrm{CV}=14.67 \\
\mathrm{~W}=0.09+0.01^{*} ; \mathrm{CV}=17.58\end{array}$ \\
\hline 13. & Rosette Crystal $(\mathrm{mm})$ & $\begin{array}{r}\mathrm{L}=0.09+0.02 ; \mathrm{CV}=22.82 \\
\mathrm{~W}=0.048+0.01 ; \mathrm{CV}=25.00\end{array}$ & $\begin{array}{r}\mathrm{L}=0.099+0.012 ; \mathrm{CV}=12.12 \\
\mathrm{~W}=0.06+0.03 * * ; \mathrm{CV}=50.00\end{array}$ \\
\hline 14. & Glandular $(\mathrm{mm})$ & $\begin{array}{r}\mathrm{L}=0.069+0.003 ; \mathrm{CV}=4.34 \\
\mathrm{~W}=0.035+0.02 ; \mathrm{CV}=60.00\end{array}$ & $\begin{array}{r}\mathrm{L}=0.051+0.004 * ; \mathrm{CV}=7.84 \\
\mathrm{~W}=0.03+0.01^{* * *} ; \mathrm{CV}=31.25\end{array}$ \\
\hline 15. & Unicellular and Warty $(\mathrm{mm})$ & $\begin{array}{r}\mathrm{L}=0.100+0.01 ; \mathrm{CV}=12.00 \\
\mathrm{~W}=0.028+0.006 ; \mathrm{CV}=0.49\end{array}$ & $\mathrm{Absent}$ \\
\hline 16. & Multicellular $(\mathrm{mm})$ & $\begin{array}{r}\mathrm{L}=0.61+0.003 ; \mathrm{CV}=36.33 \\
\mathrm{~W}=0.022+0.008 ; \mathrm{CV}=18.42\end{array}$ & $\begin{array}{r}\mathrm{L}=0.035+0.005 ; \mathrm{CV}=14.28 \\
\mathrm{R}=0.038+0.007 * ; \mathrm{CV}=18.42\end{array}$ \\
\hline 17. & Vein Islets Number & $\mathrm{R}=12-16$ & $\mathrm{R}=8-10$ \\
& & $\mathrm{SD}=14.001 .62 ; \mathrm{CV}=11.65$ & $\mathrm{SD}=8.66+0.94 * * ; \mathrm{CV}=10.88$ \\
\hline 18. & Vein Termination Number & $\mathrm{R}=14-24$ & $\mathrm{R}=18-36$ \\
& & $\mathrm{SD}=18.00+4.32 ; \mathrm{CV}=24.00$ & $\mathrm{SD}=24.66+6.06 ; \mathrm{CV}=24.55$ \\
\hline
\end{tabular}

Significant at $0.1 \%$--* $^{*} 1.0 \%--* *, 5.0 \%--* * *$

\section{Chemical Analysis:}

Preliminary Colour Reaction Tests:- The result shows the presence of alkaloids, lignin, tannins, carbohydrates, proteins, sugar, suberin, glucosides, saponin, flavin, steroids and oils in both the cases. Degree of change in colour reaction tests are tabulated in table-3.

Table 3: Colour reaction tests of Boerhaavia diffusa Linn. growing in non-polluted and polluted areas.

\begin{tabular}{|c|c|c|c|c|c|}
\hline \multirow[t]{2}{*}{ S. No. } & \multirow[t]{2}{*}{ Reagents } & \multirow[t]{2}{*}{ Test for } & \multirow{2}{*}{$\begin{array}{l}\text { Nature of } \\
\text { Colour }\end{array}$} & \multicolumn{2}{|c|}{ Degree of Changes } \\
\hline & & & & Non-polluted & Polluted \\
\hline 1. & Dragenorff's Reagent \{Cromwell (1955)\} & Alkaloid & Orange ppt & +++ & ++ \\
\hline 2. & Mayer's Reagent & Alkaloid & Brown & +++ & + \\
\hline 3. & $\begin{array}{l}\text { Wagner's Reagent } \\
\text { (Trease and Evans (1983)) }\end{array}$ & Alkaloid & Brown & ++++ & ++ \\
\hline 4. & Tannic Acid & Alkaloid & Turbidity & +++ & ++ \\
\hline 5. & Hager's Reagent & Alkaloid & Yellow & ++ & ++ \\
\hline 6. & Phloroglucinol $+\mathrm{HCl}$ & Lignin & Dark Red & +++ & ++ \\
\hline 7. & $\mathrm{FeCl} 3$ & Tannin & Black & +++ & ++ \\
\hline 8. & Molisch Test & Carbohydrates & Red & ++++ & ++ \\
\hline 9. & Millon’s Reagent & Protein & Red ppt & ++++ & ++ \\
\hline 10. & Xanthoproteic Test & Protein & Yellow & ++++ & +++ \\
\hline 11. & Bendict’s Reagent after Heating & Sugars & Red Violet & +++ & + \\
\hline 12. & $\begin{array}{l}\text { Sample + Heating with Strong } \mathrm{KOH}+ \\
\mathrm{H}_{2} \mathrm{SO}_{4}\end{array}$ & Suberin & Red Black & ++++ & ++ \\
\hline 13. & Molisch Test after Hydrolysis & Glucoside & Yellow & ++++ & ++ \\
\hline 14. & Plant Powder $+\mathrm{H}_{2} \mathrm{O}+$ Shake & Saponin & Froth $(\mathrm{W})$ & ++++ & ++ \\
\hline 15. & Mg Powder + Conc. HCl & Flavin & Red & ++ & + \\
\hline 16. & Libermann's Buchard Reagent & Steroids & Violet & +++ & + \\
\hline 17. & Sudan IV & Oils & Violet & ++++ & ++ \\
\hline
\end{tabular}


TLC:- The number of spots are 4-8 in non-polluted and 2 in polluted samples (Plate-4). There Rf values are tabulated in table-4.

Table 4: The Rf values of Boerhaavia diffusa Linn. growing in non-polluted and polluted areas.

\begin{tabular}{|l|l|c|c|}
\hline S. No. & Wavelengths & Non - Polluted & Polluted \\
\cline { 3 - 4 } & & Rf - values & Rf - values \\
\hline 1. & Sunlight $($ visible) & $0.30,0.34,0.80,0.88$ & $0.80,0.88$ \\
\hline 2. & UV Light $(354 \mathrm{~nm})$ & $0.26,0.30,0.34,0.36,0.40,0.80,0.88,0.93$ & $0.80,0.88$ \\
\hline 3. & UV Light $(365 \mathrm{~nm})$ & $0.30,0.34,0.36,0.40,0.80,0.88,0.93$ & $0.80,0.88$ \\
\hline
\end{tabular}

\section{PHYSICALEVALUATION}

Fluorescence Behaviour of Plants:-There were no significant results observed with fluorescence behaviour of plant powder and its extracts except some difference in coloursonly.

Extractive Values and Ash Values:- The percentage of water and alcoholic soluble extractives are lower in those plants collected from polluted sites, but LOD is higher in polluted samples. Total ash, acid insoluble and sulphated ash are higher in those samples which are collected from the polluted areas. The mean values are tabulated in table-5.

\section{PHYSICALEVALUATION}

Fluorescence Behaviour of Plants: There were no significant results observed with fluorescence behaviour of plant powder and its extracts except some difference in coloursonly.

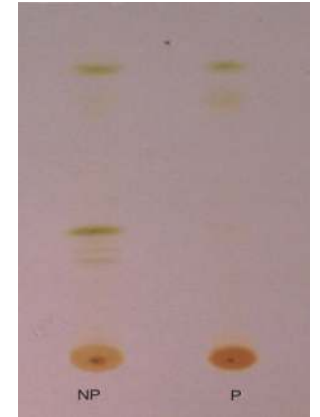

Plate 5: The Rf values of Boerhaavia diffusa Linn.growing in non-polluted and polluted areas.

Extractive Values and Ash Values: The percentage of water and alcoholic soluble extractives are lower in those plants collected from polluted sites, but LOD is higher in polluted samples. Total ash, acid insoluble and sulphated ash are higher in those samples which are collected from the polluted areas. The mean values are tabulated in table- 5 .

Table 5: Extractive and Ash values of Boerhaavia diffusa Linn. growing in non-polluted and polluted areas.

\begin{tabular}{|l|l|l|l|}
\hline \multicolumn{3}{|c|}{ Extractive Values and Ash values (\%) } \\
\hline S. No. & Parameters & Non-polluted & Polluted \\
\hline 1. & Water Soluble & $30.250+1.400 ; \mathrm{CV}=4.620$ & $27.090+0.960 * * * ; \mathrm{CV}=3.543$ \\
\hline 2. & Alcohol Soluble & $49.730+0.820 ; \mathrm{CV}=1.650$ & $31.880+0.210^{*} ; \mathrm{CV}=0.660$ \\
\hline 3. & LOD & $15.060+0.910 ; \mathrm{CV}=6.042$ & $25.600+1.960^{* * *} ; \mathrm{CV}=7.650$ \\
\hline 4. & Tota Ash Value & $9.150+1.070 ; \mathrm{CV}=11.780$ & $14.010+0.800^{* *} ; \mathrm{CV}=5.600$ \\
\hline 5. & Acid Insoluble & $1.39+0.140 \quad ; \mathrm{CV}=10.066$ & $6.560+0.390^{*} \quad ; \mathrm{CV}=5.950$ \\
\hline 6. & Sulphated Ash & $18.650+1.870 ; \mathrm{CV}=10.030$ & $25.830+1.290 * * * ; \mathrm{CV}=5.00$ \\
\hline
\end{tabular}




\section{DISCUSSION}

The effluent samples collected from the selected industry was analysed for different physicochemical parameters and has higher values than the recommended values by I.S.I. Similar results were also obtained by Kumar, et al.(1991).The critical observations on the data clearly indicate that the plants growing in polluted sites were badly affected and there were a significant reduction in number of parameters studied as compared to the control plants. Morphological characters were found to be decreased in the selected plant collected from polluted area. Similar observations are reported by Palaniswamy et al. (1995). Angadi and Mathad (1998) have studied the effect of copper, cadmium and mercury on the morphological, physiological and biochemical characteristics of Scenedesmus quadricauada (Turp) de Breb. and found the maximum inhibition in the growth, chlorophylls, total DNA, total RNA and protein contents of cells at the higher metal concentrations. Therefore it is observed from various studies that the same species respond differently under different conditions.

Thick cuticle observed in the transverse sections of the stem collected from the polluted area also matched with the findings of Percy et al (,1992). Cuticle is the first point of attack of pollutants; our results indicated an increase in the thickness in cuticle at the polluted sites which indicates that the plants have an effective barrier for the pollutants entry. Trivedi \& Singh (1989 \&1990) studied the epidermal features (stomatal density and index) of different plants (Boerhaavia diffusa Linn. and Amaranthus viridis Linn.) under the impact of air pollution. Significant reduction in cell size of the pollution effected plants was also reported by Ansari and Iqbal (1992). The reduced length of vessel elements coupled with their augmented frequency appears to be the significant adaptations to the stress of pollution. In contrast to the above workers more number of parameters (xylem vessels) observed in the plant samples collected from polluted area over to control population in Datura inoxia by Iqbalet al.(1986). Chaudhari and Patil (2001) also observed the inhibition and stimulation in xylem and phloem in pith region under the stress conditions of polluted water. In present findings there is less secondary growth observed in most of the selected plants collected from polluted area. Jabeen and Abraham (1998) also showed less secondary tissue in Largerstroemia reginae and Alstonia scholaris trees exposed to air pollutants.

Our result indicates that less trichomes frequency, more stomata, presences of collenchyma layers, less layered spongy parenchyma with smaller cell size, less layered ground tissue, decreased ratio of stomatal index and palisade; more numbers of crystals with bigger sizein leaves of polluted plant samples. Similar observations were noted by Faroqui\& Singh (1990). Low stomatal frequency were observed in the plants grown in polluted areas, which may be an adaptation of ecotypic significance in regulating the limited and controlled entry of harmful gaseous pollutants into the plants tissues, especially when the plant grown in polluted area. Physical evaluation included fluorescence behaviour, extractive and total ash values. The plant samples collected from polluted areas showed quick differentiations to fluorescence behaviour. Water and alcohol extractive values were lowered collected from polluted areas. Ash values were higher comparatively in polluted plant samples. Same observations were made by Sharma and Habib(1995). The percentage of ash content was higher in the plant samples collected from polluted areas as compared to control because ash content of the plants is the direct manifestation of bioaccumulation of minerals observed as macronutrient and micronutrients which take up different functions.

From the observation of TLC, it was seen that the number of spots were decreased in the samples of 
plant collected from the polluted areas. Similar observations were studied by Mashaly (1988).

In order to determine the quality of medicinal plants with regard to authenticity pharmacognostical characters viz. macroscopical, anatomical, powder analysis, chemical analysis, TLC, fluorescence behaviour, extractive values and ash values are very important. Anatomy often proves very useful for individual identification of plants so microscopical methods are of great value towards their identification and differentiation of the authenticity of the plant drugs. They provide evidences concerning relationship of groups such as families or help to establish the affinities of genera of uncertain taxonomic status. The number of stomata and epidermal cells, vein-islets and vein termination number per unit area, palisade ratio, stomatal index etc. give constant structure of different species of plants. Moreover, different types of stomata, crystals, fibers, trichomes etc. present in powdered drug help in the identification of plants or differentiation in comparison of same plant, which are collected from the industrial area.

\section{CONCLUSION}

It is concluded that the plant under the pollution stress must have suffered in its drug quality. These changes might be due to the presence of heavy metals in effluent.

\section{REFERENCE}

1. Angadi, S.B. and Mathad, Pratima. (1998): Effect of copper, cadmium and mercury on the morphological, physiological and biochemical characteristics of Sceredesmus quadricallda. J. Environ. Biol.19(2):119-124.

2. Ansari, M. K. and Iqbal, M. (1992): Impact of coal smoke pollution on the growth performance of Achyranthes aspera Linn. New Botanist, XIX: 81-84.

3. Bindu, S.J. and Bera, A.K. (2001): Impact of Cadmium toxicity on leaf area, stomatal frequency, stomatal index and pigment content in mungbean seedlings, J. Environ. Biol. 22 (4):307-309.

4. Chaudhari, G. S. and Patil, Y. (2001): Effect of pollution water of Tapti river on the physiology of stem anatomy of its bank vegetation. Journal of Ecobiology, 13(3): 223240.

5. Faroqui, F. and Singh, D. (1990): Effect of Mathura refinery emissions on foliage of Dalbergia sissoo Roxb. J. Ind. Bot. Soc., Abs 69.

6. Iqbal, M., Ahmad, Z., Kabir, I., Mahmooduzzafar and Kalimullah (1986): Stem anatomy of Datura inoxia in relation to coal smoke pollution. J. Sci. Res., 8:103-105.

7. Iqbal, M., Mahmooduzzafar, K., Kalimullah, I. and Ahmad, Z. (1987): The effect of air pollution on the stem anatomy of Lantana camara L. J. Sci. Res., 9:121-122.

8. Jabeen, C. and Abraham, S. (1998): Histological changes in Lagerstroemiaregime and Alstonia scholaris exposed to air pollutants. J. Environ. Biol, 19(1): 79-82.

9. Kumar, Nirmal J. I., Nirmal, Rita and Rana, B.C. (1991): Physico-chemical properties of certain industrial effluents of central Gujrat, India. Jr. Ind. Poll. Cont. 7 (1):17-24.

10. Metcalfe, C., R. (1980): Anatomy of Dicotyledonous (Claredon Press, Oxford).

11. Mashaly, A. A. (1988): Further studies of the interaction between certain soil factors and root-knot nematode in relation to some nutrients availability. Ph. D. Thesis, Fac. Agric., Menofiya University.

12. Palaniswamy, M., Gunamani, T. and Swaminathan, S. (1995): Effect of air pollution caused by automobile exhaust gases on crop plants. Proc. Acad. Environ. Biol., 4 : 255-260.

13. Percy, K. E., Jensen, K. T. and Mcquattia, C. J. (1992): Effect of O3 and acidic fog on red 
spruce needle epicuticular wax production, chemical composition, cuticular membrane, ultrastructure and needle wettability. New Phytol., 121:71-80.

14. Sharma, B. K. and Habib, I. (1995): Irrigational impact of rubber factory effluent on elemental bioaccumulation and metabolite concentration on component parts of Brassica campestris var varuna. New Botanist, 22:1-12.

15. Tample-Smith, M. G. and Koen, T. B. 1982 : Comparative response of Poppy (Papaver somniferum L.) and eight crops and vegetable species to manganese excess in solution culture. J. Plant Nutrition. 5: 1153.
16. Trivedi, R. K. and Goel, P. K. (1986) : Chemical and biochemical methods for water pollution studies. Environ. Pub. Karad. India.

17. Trivedi, M. L. and Singh, R. S. (1989) : Epidermal features as indicators of air pollution in Amaranthus viridis Linn. New Botanist.6(1-4): 197-201.

18. Trivedi, M. L. and Singh, R. S. (1990) : Effect of air pollution on epidermal structure of Croton bonplandianum Baill. New Botanist. 17(3-4):225-229.

19. World Health Organisation, Geneva (1998) : Basic Tests for Drugs, Pharmaceutical Substances, Medicinal Plants Materials and Dosage Forms. 